удк 330.332

\title{
БАНКІВСЬКІ ІННОВАЦІЇ В УМОВАХ ФОРМУВАННЯ ЦИФРОВОÏ ЕКОНОМІКИ
}

\section{BANKING INNOVATIONS IN THE CONDITIONS OF DIGITAL ECONOMY FORMATION}

\author{
Карлін Микола Іванович \\ доктор економічних наук, профресор, \\ Волинський національний університет імені Лесі Українки \\ ORCID: https://orcid.org/0000-0002-1421-1066 \\ Шматковська Тетяна Олександрівна \\ кандидат економічних наук, доцент, \\ Волинський національний університет імені Лесі Українки \\ ORCID: https://orcid.org/0000-0003-2771-9982 \\ Борисюк Олена Володимирівна \\ кандидат економічних наук, доцент, \\ Волинський національний університет імені Лесі Українки \\ ORCID: https://orcid.org/0000-0002-9411-4118 \\ Karlin Mykola, Shmatkovska Tetiana, Borysiuk Olena \\ Lesya Ukrainka Volyn National University
}

\begin{abstract}
Трансформація системи економічних відносин, яка відбувається під впливом інтенсисрікації технологічного розвитку та науково-технічного прогресу, значно впливають на взаємодію банків та їх клієнтів в процесі здійснення банківської діяльності. При цьому, як показує практика, за останні двадцять років кардинально змінилися принципи взаємодії цих суб'єктів банківського ринку 3 появою та наступним широким розповсюдженням мережевих технологій. У статті розглядається специфіка фрормування підходів до впровадження банківських інновацій, зокрема - конкретизуються фрактори та чинники, що впливають на поширення систем онлайн-банкінгу. Досліджено особливості впливу нових технологій на фоормування банківського ринку в умовах цифровізації економічних відносин. Визначено, що забезпечення ефективного функціонування та розвитку онлайн-банкінгу в умовах формування цифрової економіки сприяє загальному підвищенню конкурентоспроможності банківських установ.
\end{abstract}

Ключові слова: банки, інновації, онлайн-банкінг, цифрова економіка, діджиталізація.

Трансформация системы экономических отношений, которая происходит под влиянием интенсисикации технологического развития и научно-технического прогресса, значительно влияют на взаимодействие банков и их клиентов в процессе осуществления банковской деятельности. При этом, как показывает практика, за последние двадцать лет кардинально изменились принципы взаимодействия этих субъектов банковского рынка с появлением и последующим широким распространением сетевых технологий. В статье рассматривается специфика фрормирования подходов к внедрению банковских инноваций, в частности - конкретизируются фракторы и фракторы, влияющие на распространение систем онлайн-банкинга. Исследованы особенности влияния новых технологий на формирование банковского рынка в условиях цифровизации экономических отношений. Определено, что обеспечение эфффективного фуннционирования и развития онлайн-банкинга в условиях формирования цифровой экономики способствует общему повышению конкурентоспособности банковских учреждений.

Ключевые слова: банки, инновации, онлайн-банкинг, цифровая экономика, диджитализация.

The transformation of the system of economic relations, which takes place under the influence of the intensification of technological development and scientific and technological progress, significantly affect the interaction of banks and their customers in the process of banking. At the same time, as practice shows, over the past twenty years, the principles of interaction of these actors in the banking market have changed dramatically with the emergence and subsequent widespread use of network technologies. And if earlier settlements were the exclusive pre- 
rogative of the bank, now any client - whether an individual or a legal entity is able to make payments independently, using online banking systems. Therefore, it is the innovation component that currently determines the efficiency of banking institutions in the financial market. The article considers the specifics of the formation of approaches to the implementation of banking innovations, in particular - specifies the factors and factors influencing the spread of online banking systems. The peculiarities of the influence of new technologies on the formation of the banking market in the conditions of digitalization of economic relations are investigated. It is determined that ensuring the effective functioning and development of online banking in the formation of the digital economy contributes to the overall increase in the competitiveness of banking institutions. It is investigated that the main direction of innovations in the field of banking recently is the technological improvement of the bank's customer service system through the formation of online banking systems. The main element that provides a competitive advantage for a commercial bank in the online banking market is the use of new technical elements that emerged in the process of digitalization of economic relations - cognitive technologies, artificial intelligence, chatbots and more. The overall efficiency of online banking as an innovative element is determined by its accessibility for the bank's customers and ease of operation in various applications and from different hardware.

Keywords: banks, innovations, online banking, digital economy, digitalization.

Постановка проблеми. Особливостями сучасного етапу трансорормації системи економічних відносин, в тому числі - на фрінансових ринках, є інтенсивний розвиток нових технологій, що активно впроваджуються в діяльність банківських установ. При цьому, якщо ще 10-15 років тому проведення будьяких банківських операцій було можливим виключно працівниками самого банку, або потребувало використання спеціалізованого програмного забезпечення (прикладом таких технологій можуть бути первинні системи клієнт-банк), то в сучасних умовах технічний прогрес розширив межі застосування спеціалізованих програмних та апаратних засобів, за допомогою яких клієнти банку можуть здійснювати практично будь-які операції на інтуїтивно зрозумілому рівні за допомогою програмних додатків, що є доступними в режимі он-лайн на будь-яких гаджетах.

Наслідком таких трансформацій стала необхідність посилення гнучкості банків щодо співпраці із своїми клієнтами. Широке впровадження цифрових технологій та банківських інновацій в систему обслуговування клієнтів банку дозволяє останнім значно економити на персоналі та кількості утримуваних відділень. 3 іншого боку, така економія потребує розробки нової стратегії банківської діяльності задля підтримання тісного контакту з клієнтами в умовах жорсткої конкуренції на банківському та фрінансовому ринку. Відтак, врахування впливу запровадження банківських інновацій на їх фрункціонування потребує додаткового опрацювання даної проблематики.

Аналіз останніх досліджень і публікацій. Дослідженням специфрічних особливостей впровадження інноваційних продуктів у банківську діяльність присвячено чимало праць багатьох авторитетних науковців та практиків. Зокрема, значний внесок у вивчення даного питання здійснили такі зарубіжні дослідники, як М. І. Дзямулич [1], Л. В. Мороз [2], Р. І. Содома [3], О. В. Стащук [4], Н. М. Чиж [5] та інші.

Загалом сучасна економічна наука має у своєму розпорядженні значні напрацювання у сорері банківських інновацій. Проте особливості формування цифррової економіки призводять до необхідності перегляду традиційних підходів щодо банківських інновацій.

Постановка завдання. Практика досліджень щодо впровадження новацій в комплексні рішення щодо банківських продуктів базується на рішеннях, котрі були розроблені в період фрормування розгалужених мережевих технологій. Однак, інтенсивний розвиток науково-технічного прогресу та надзвичайне поширення цифрових технологій у фрінансовій сорері призводить до необхідності перегляду усталених рішень у ссрері формування програмних банківських продуктів у зв'язку із появою нових програмних та апаратних рішень, що сприяють більшому їх розповсюдженню. Тому на нашу думку існує об'єктивна потреба пошуку нових підходів щодо впровадження інноваційних банківських продуктів в діяльність комерційних банків з врахуванням нових технологій, що базуються на рішеннях цисрової економіки.

Виклад основного матеріалу дослідження. Особливості фуннкціонування банківської системи в умовах технічних та технологічних трансформацій, безумовно потребує оперативного реагування 3 боку менеджменту комерційних банків щодо фрормування нових та актуальних банківських продуктів та рішень, котрі пропонуються клієнтам. Саме це визначає необхідність інноваційної діяльності банківських установ, яка в практичній площині розкривається через два головні напрямки:

1. Інновації, пов'язані із впровадженням нових технологій безпосередньо в систему 
реального банківського обслуговування клієнтів, які включать в себе оснащення банків платіжними терміналами, банкоматами, розумними відділеннями, які працюють без обслуговуючого персоналу тощо.

2. Інноваційні рішення у ссрері розробки нових програмних продуктів та додатків, які застосовуються клієнтами банку в режимі онлайн із залученням різноманітних апаратних засобів та гаджетів.

Крім того, як зазначає Н. М. Чиж: «основною причиною виникнення інновацій у банківській сорері, на нашу думку, як і в інших галузях економіки, $є$ перспектива отримання прибутку. Проте сприятливі умови виникнення банківських інновацій створюються, перш за все, змінами зовнішнього банківського середовища. Основним інституційним фрактором, що впливає на процес розробки та впровадження банківських інновацій, $€$ існуюча у країні система регулювання банківської діяльності, а також законодавство, що визначає розвиток інших фрінансових ринків» [5, с. 405].

Якщо ж вести мову про конкретні напрямки та рішення щодо впровадження інноваційних продуктів у діяльність комерційних банків, то можна стверджувати, що 90\% з них стосуються технічних, програмних та апаратних рішень, котрі пов'язані з технологіями обслуговування клієнтів та веденням банківських операцій за допомогою онлайн-банкінгу. При цьому варто зауважити, що така тенденція зумовлена саме посиленням конкуренції на банківському ринку, оскільки у зв'язку з масштабним поширенням нових мережевих технологій зв'язку банки можуть працювати навіть на тих ринках, які раніше не цікавили їх з-за відсутності фрізичних відділень або інших представництв на певній території. Наразі ж, відбувається поширення впливу банківських установ на ринкові ніші, які колись були виключною прерогативою дрібних регіональних або спеціалізованих банків. Більше того, транснаціональні фрінансово-промислові групи отримують доступ до специфрічних секторів національних ринків різних країн, на яких раніше вони могли працювати з певними обмеженнями, а інновації у сорері забезпечення банківського обслуговування за допомогою онлайн-банкінгу дають змогу обійти ці обмеження.

3 іншого боку, банківські клієнти, які використовують онлайн-банкінг, одержують можливість цілодобового доступу до здійснення різноманітних банківських операцій з своїми коштами, що нівелює поняття операційного банківського дня, котре диктувало обмеження у сорері здійснення платежів ще 15 років тому.

Тому, оскільки більшість банківських інновацій реалізуються у сорері онлайн-банкінгу, то необхідно зазначити про його специфріку. Мається на увазі, що технічні рішення щодо його фуннкціонування базуються на технологіях «клієнт-банку», які фрормувалися в умовах обмеженої комунікаційної системи початку 2000-х років і включали в себе змішані канали телефронного, мобільного та інтернет-зв'язку між банком та його клієнтами. Функціонально онлайн-банкінг включає в себе три основні напрямки, які характеризуються різною технічною спрямованістю програмних рішень, які повинні закладатися в їх інноваційне вдосконалення. При цьому необхідно зауважити, що базовим і найбільш вдалим елементом онлайн-банкінгу на даний час $є$ інтернет-банкінг, оскільки тотальна більшість усіх програмних продуктів та технологій, які, імплементуючись в систему економічних відносин, фрормують собою нову цифррову економіку, базуються на комунікаційних технологіях інтернети-зв'язку. Крім того, як показує практика, саме даний вид комунікацій розвивається найбільш динамічно і має неабиякі резерви для подальшого поширення. Доцільно згадати про мережу Star Link, яка реалізується компанією SpaceX і має на меті формування глобальної мережі супутникового інтернету без будь-яких обмежень.

В даному аспекті необхідно зазначити, що саме глобальне поширення інтернет-комунікацій загрожує зникненням такому напрямку онлайн-банкінгу, як телебанкінг. Обслуговування клієнтів банку за допомогою додатків в мобільних телесронах значною мірою пересікається 3 інтернет-банкінгом в технічних рішеннях щодо програмної оболонки додатків, через які відбувається здійснення операцій клієнтами банку. Можна навіть стверджувати, що вони приходять до уніфікованого вигляду, залишаючи за собою лише різницю у способі формування комунікаційного каналу - якщо інтернет-банкінг працює виключно через канали інтернети-зв'язку, то телебанкінг реалізує ті ж фрункції, але за допомогою каналів телесронного зв'язку та безпровідного доступу до зв'язку з серверами самого банку.

Зрештою, залишається мобільний банкінг. На даний час він займає незначну частину у загальній сукупності системи онлайн-банкінгу в усьому світі. Проте, як засвідчують експерти, за допомогою мобільного банкінгу здійснюються значна частка операцій крупних клієн- 
тів банків, які мають у своєму розпорядженні значні кошти на рахунках. Це обумовлюється тим, що реалізація управління рахунками та проведення банківських операцій здійснюються голосом або за допомогою телефонного контакту 3 оператором банку, що підвищує загальну безпеку усіх операцій. В даний час головні інноваційні рішення у сфрері мобільного банкінгу реалізуються за допомогою рішень штучного інтелекту та когнітивних технологій, коли програма розпізнавання голосу та актуально налаштовані під конкретні операцій чатботи дають можливість інтенсивно розвивати даний напрямок мобільного банкінгу, який пропонується, зазвичай, для VIP-клієнтів банківських установ.

Отже, головні операції, які стосуються впровадження інноваційних рішень в системи інтернет-банкінгу в сучасних умовах, базуються на програмних рішеннях щодо вдосконаленні системи обслуговування клієнтів за допомогою простого та зрозумілого інтерфейсу, який може однаково ефективно застосовуватися у різних додатках та на різних апаратних засобах. Крім того, важливим елементом, який потребує інноваційного вдосконалення, $€$ забезпечення конфріденційності та безпеки банківських операцій, які проводяться клієнтами банків за допомогою інтернет-банкінгу. Відтак, саме практична реалізація зазначених інноваційних удосконалень сприяє фрормуванню системи сучасного інтернет-банкінгу (рис. 1).

Таким чином конкретна конкурентна позиція комерційних банків в системі фрінансового ринку значною мірою визначається за допомогою якості та інноваційності розвитку систем інтернет-банкінгу. Більше того, банківська конкуренція наразі розгортається не лише у сорері доступу до дешевих фрінансових ресурсів, які будуть генерувати для банківських установ операційних дохід, але й у сорері співпраці 3 клієнтами, які будуть ці ресурси використовувати. А ця співпраця, у свою чергу, значною мірою залежить від якості технічних рішень, які закладені в системах інтернет-банкінгу кожного окремого банку, що $€$ учасником ринку.

На основі цього можна стверджувати, що ефективна діяльність банківських установ з одного боку $є$ неможливою без залучення систем онлайн-банкінгу. Але з іншої сторони, сам по собі онлайн-банкінг теж не може дозволити банку почувати себе упевнено на ринку,

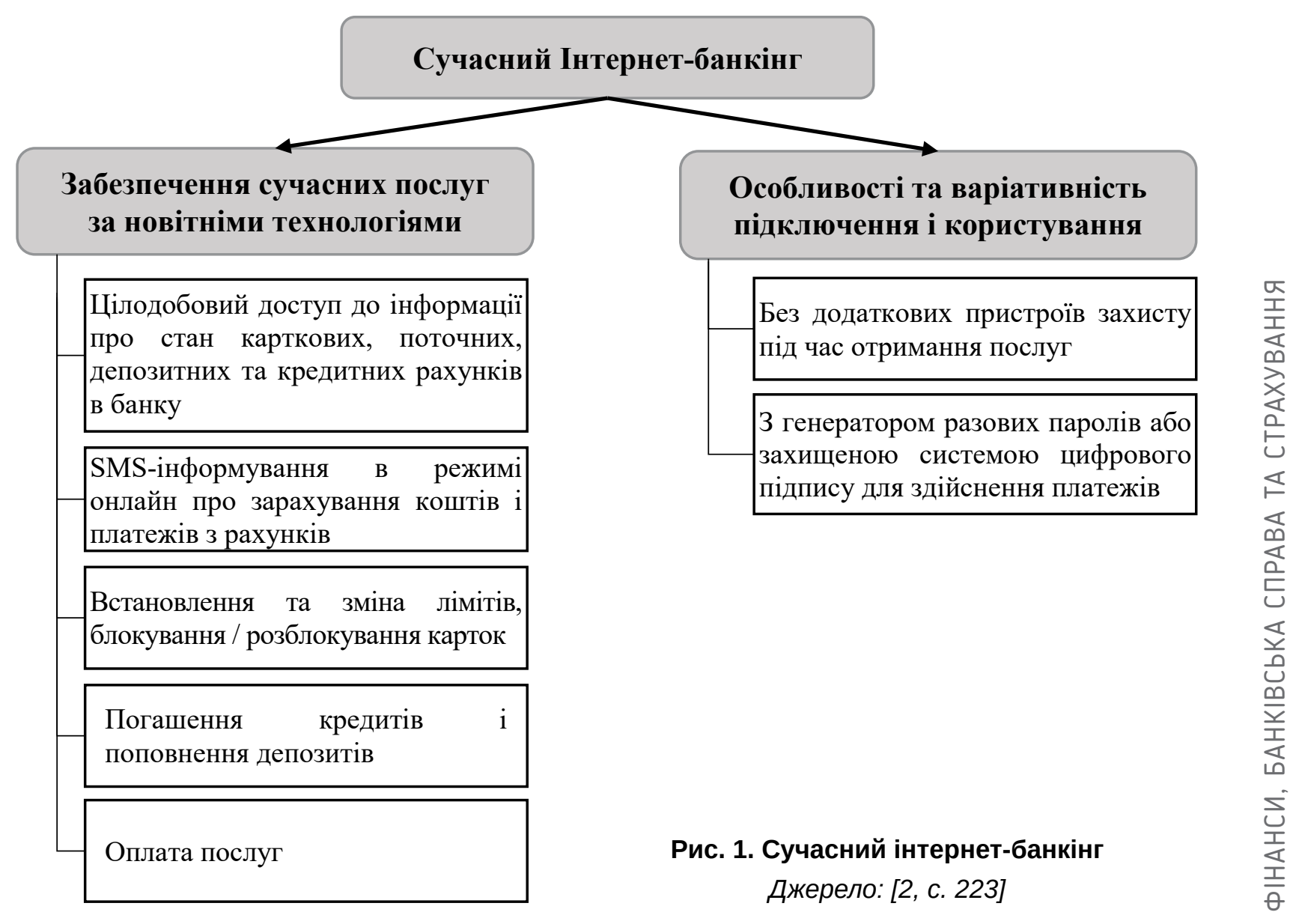


оскільки потребує постійного технічного та програмного оновлення відповідно до нових тенденцій технологічного розвитку.

Висновки. Отже, в основі розвитку та поширення онлайн-банкінгу лежать дві фрундаментальні причини. По-перше, комерційні банки отримують відчутну економію коштів, пропонуючи банківські послуги за допомогою інноваційних рішень через онлайн-банкінг. По-друге, комерційні банки, скорочуючи свої фріліальні мережі та зменшуючи чисельність обслуговуючого персоналу, самі відкривають для своїх клієнтів шлях до каналів самообслуговування, котрі реалізуються через систему онлайн-банкінгу. При цьому додатковим позитивним моментом таких рішень $€$ те, що в попередні часи досить багато клієнтів вважали, що банківське обслуговування у фріліях займає занадто багато часу та зусиль.

Також необхідно зазначити, що в умовах формування цифрової економіки саме Інтернет-банкінг $€$ найбільш вигідним і найпривабливішим сегментом для комерційних банків, оскільки дозволяє масово залучати нових клієнтів, а також сприяє виходу банків на нові ринки або сегменти банківського ринку, які раніше були для них недоступні. Саме тому в сучасних умовах жоден банк не може недооцінювати потужність Інтернет-банкінгу в аспекті забезпечення власної прибутковості.
Загалом можна стверджувати, що основні напрямки реалізації інноваційних рішень у сорері вдосконалення банківських продуктів, які реалізуються за допомогою онлайн-банкінгу, повинні відповідати ключових напрямкам розвитку цисррової економіки. До числа найбільш затребуваних напрямків реалізації інноваційних рішень у банківській діяльності найближчим часом можна віднести наступні:

1. Застосування когнітивних технологій та штучного інтелекту у сорері мережевого обслуговування клієнтів банку.

2. Широке впровадження хмарних технологій в систему банківського обслуговування та інтернет-банкінгу зокрема.

3. Адаптація банківських продуктів до поєднання їх 3 Інтернетом речей на програмному та апаратному рівні.

4. Масштабне застосування Великих даних в аналітичних процесах, які здійснюють банки в процесі планування своєї діяльності.

5. Орієнтація на фрормування таких бізнесмоделей банківського обслуговування, які б базувалися на банківських цисрових платформах, що значно спростить процес взаємодії банку та його клієнтів.

6. Переосмислення ролі криптовалют в забезпеченні проведення розрахунків та платежів та адаптація банківських платіжних систем під можливість використання криптовалюти як засобу платежу.

\section{СПИСОК ВИКОРИСТАНИХ ДЖЕРЕЛ:}

1. Дзямулич М.І. Сутність електронних грошей в сучасній фінансовій системі. Економічні науки. Серія «Облік та фрінанси». Збірник наукових праць. 2010. Випуск 7(25). Ч. 4. С. 181-185.

2. Мороз Л.В. Перспективи розвитку онлайн-банкінгу в Україні. Науковий вісник НЛтУ України. 2012. № 13(22). C. 218-225.

3. Содома Р.І., Марків Г.В., Східницька Г.В., Шматковська Т.О. Інноваційний проєкт з електронного банкінгу. Вісник ЛНАУ : Економіка АПК. 2019. № 26. С. 85-91.

4. Стащук О., Борисюк О., Шматковська Т. Роль банківських інновацій на фрінансовому ринку в умовах глобального фінансового простору. Економічний часопис Східноєвропейського національного університету ім. Лесі Українки. 2020. № 4(24). С. 71-79.

5. Чиж Н.М., Дзямулич М.І. Банківські інновації: проблеми та перспективи. Економічні науки. Серія «Облік та фрінанси». Збірник наукових праць. 2012. Випуск 9(33). Ч. 4. С. 403-411.

6. Yakubiv V., Sodoma R., Hrytsyna O., Shmatkovska T., Tsymbaliuk I., Marcus O., Brodska I. Development of electronic banking: A case study of Ukraine. Entrepreneurship and Sustainability Issues. 2019. Vol. 7(1). P. 219-232.

\section{REFERENCES:}

1. Dziamulych M.I. (2010). Sutnist elektronnykh groshei v suchasniy finansoviy systemi [The essence of electronic money in the modern financial system]. Ekonomichni nauky. Seria Oblik ta finansy - Economic sciences. Accounting and Finance Series, issue 7(25), part 4, p. 181-185. (in Ukrainian)

2. Moroz L.V. (2012). Perspektyvy rozvytku onlain-bankinge $v$ Ukrani [Prospects for the development of online banking in Ukraine]. Naukovyi visnyk NLTU Ukrayiny - Scientific Bulletin of NLTU of Ukraine, vol. 13(22), p. 218-225. (in Ukrainian) 
3. Sodoma R.I., Markiv G.V., Skhidnytska G.V., Shmatkovska T.O. (2019). Innovatsijnyi proect z elektronnogo bankingu [Innovative project in electronic banking]. Visnyk LNAU: Ekonomika APK - Bulletin of LNAU: Economics of agro-industrial complex, vol. 26, p. 85-91. (in Ukrainian)

4. Stashchuk O., Borysiuk O., Shmatkovskaya T. (2020) Rol bankivskivskyh innovatsii na finansovomu rynku v umovakh globalnogo finansovyk prostoru [The role of banking innovations in the financial market in the global financial space]. Ekonomichnyi chasopys Shidnoevropeiskogo natsionalnogo universytetu im. Lesi Ukrainky - Economic Journal of Lesya Ukrainka Eastern European National University, vol. 4, no. 24, p. 71-79. (in Ukrainian)

5. Chyzh N.M., Dziamulych M.I. (2012) Bankivski innovatsii: problemy ta perspektyvy [Banking innovations: problems and prospects]. Ekonomichni nauky. Seria Oblik ta finansy - Economic sciences. Accounting and Finance Series, issue 9(33), part 4, pp. 403-411. (in Ukrainian)

6. Yakubiv V., Sodoma R., Hrytsyna O., Shmatkovska T., Tsymbaliuk I., Marcus O., Brodska I. (2019) Development of electronic banking: A case study of Ukraine. Entrepreneurship and Sustainability Issues, vol. 7(1), pp. $219-232$. 